\title{
EVALUASI BIAYA DIFERENSIAL DALAM PENGAMBILAN KEPUTUSAN MENERIMA ATAU MENOLAK PESANAN KHUSUS PADA UD.KAREMA
}

\author{
Rivo Jeaner Mangare ${ }^{1}$ \\ Jenny Morasa ${ }^{2}$ \\ Sherly Pinatik ${ }^{3}$ \\ Fakultas Ekonomi dan Bisnis Universitas Sam Ratulangi \\ Manado \\ E-mail : $\underline{\text { rivojeanerID@gmail.com }}$
}

\begin{abstract}
Abstract: The economic growth in Indonesia is rapidly increasing, making businesses in Indonesia to grow faster and move forward. It is demanding textile industries in order to produce quality products and in accordance with the development of the fashion world continues to grow. This study aims to describe the differential cost evaluation in the decision to accept or reject the special order on the company UD.Karema. Type of research method used is quantitative descriptive with case study approach. Location of research conducted at UD.Karema.. Results from this study are: the company will earn a profit contribution of Rp.19.547.917 if accept the special orders. According to research, company must accept special orders for the profit contribution. UD.Karema leaders should apply the differential cost calculation for making decisions to accept or reject special order.
\end{abstract}

Keywords : Differential Cost, Decision Making, Accept or Reject, Special Order

\section{Latar Belakang}

\section{PENDAHULUAN}

Tujuan utama perusahaan menurut theory of the firm adalah untuk memaksimumkan kekayaan atau nilai perusahaan (Value of the firm) (Salvatore, 2005). Oleh karena itu, manajemen memiliki peran penting dalam perkembangan tercapainya tujuan perusahaan. Baik tujuan jangka pendek maupun tujuan jangka panjang.

Salah satu langkah untuk bersaing dengan perusahaan lain adalah dengan keputusan manajemen dari perencanaan. Pada perencanaan, manajemen sudah dihadapkan dengan beberapa pengambilan keputusan yang mencakup beberapa alternatif yang harus dipilih, artinya pihak manajemen banyak menghadapi pengambilan keputusan. Pengambilan keputusan selalu menyangkut masa yang akan datang sehingga data yang akan datang yang relevan dengan data yang tersedia.

Menurut Darsono (2009:259) ada 5 keputusan khusus yang diambil oleh manajemen yaitu membeli atau membuat sendiri, menjual atau memproses lebih lanjut suatu produk, menghentikan atau melanjutkan produksi produk tertentu atau kegiatan usaha suatu bagian perusahaan, menerima atau menolak pesanan khusus, dan menyewakan atau menjual fasilitas perusahaan.

Menerima atau menolak pesanan khusus (special order decision) yaitu keadaan dimana perusahaan harus mengambil keputusan antara menerima atau menolak pesanan khusus, pesanan khusus yang ditawarkan oleh pelanggan dibawah harga jual produk namun menarik bagi perusahaan karena perusahaan masih memiliki kapasitas mesin yang menganggur. Manajemen membutuhkan evaluasi biaya diferensial untuk membantu dalam pengambilan keputusan untuk menerima atau menolak pesanan khusus.

UD.Karema adalah salah satu perusahaan yang bergerak pada industri tekstil di Sulawesi Utara. Dimana dalam menjalankan usahanya UD.Karema sering mendapatkan pesanan khusus dari konsumen, dengan adanya pesanan khusus dari konsumen perusahaan membutuhkan informasi biaya diferensial untuk menentukan keputusan menerima atau menolak pesanan khusus tersebut. Berdasarkan latar belakang permasalahan, masalah penelitian ini dapat dirumuskan sebagai berikut : "Bagaimana Evaluasi Biaya Diferensial dalam Pengambilan Keputusan Menerima atau Menolak Pesanan khusus pada UD.Karema?".

\section{Tujuan Penelitian}

Tujuan yang ingin dicapai penelitian ini adalah untuk mengetahui apakah biaya diferensial (Differential Cost) UD.KAREMA dalam kaitannya dengan pengambilan keputusan menerima atau menolak pesanan khusus dapat memberikan laba kontribusi bagi perusahan. 


\section{Konsep Akuntansi}

\section{TINJAUAN PUSTAKA}

Horgren (2009:4), mendefinisikan bahwa akuntansi adalah sistem akuntansi yang mengukur aktivitas bisnis, memproses data menjadi laporan, dan mengkomunikasikan hasilnya kepada para pengambil keputusan. Arfan (2009:2), mengartikan akuntansi dapat di pandang sebagai suatu proses atau kegiatan yang meliputi proses pengidentifikasian, pengukuran, pencatatan, pengklasifikasian, penguraian, penggabungan, pengiktisaran dan penyajian data keuangan yang terjadi sebagai akibat dari kegiatan operasi suatu unit organisasi.

\section{Akuntansi Manajemen}

Simamora, (2012:13) mengartikan akuntansi manajemen adalah proses pengidentifikasian, pengukuran, penghimpunan, penganalisisan, penyusunan, penafsiran, dan pengkomunikasian informasi keuangan yang digunakan oleh manajemen untuk merencanakan, mengevaluasi, dan mengendalikan kegiatan usaha di dalam sebuah organisasi, serta untuk memastikan penggunaan dan akuntabilitas sumber daya yang tepat.

\section{Akuntansi Diferensial}

Supomo (2012 : 11) mendefinisikan bahwa akuntansi diferensial adalah adalah sebagai berikut: "Akuntansi diferensial merupakan informasi akuntansi yang menyajikan informasi mengenai taksiran pendapatan, biaya dan atau aktiva yang berbeda jika suatu tindakan tertentu dipilih, dibandingkan dengan alternatif tindakan yang lain". Berdasarkan teori di atas, informasi akuntansi diferensial berkaitan dengan masa yang akan datang. Pada tipe informasi ini tidak ada informasi masa lalu, karena penggunaan tipe informasi ini adalah untuk pemilihan alternatif tindakan. Pemilihan suatu tindakan berhubungan dengan pengambilan keputusan yang menyangkut masa yang akan datang.

\section{Pengertian Biaya}

Kautsar (2013:20) mendifinisikan biaya adalah suatu nilai tukar, pengeluaran-pengeluaran yang dilakukan untuk menjamin perolehan manfaat. Krismiaji, (2011:17) menyatakan biaya adalah kas atau ekuivalen yang dikorbankan untuk membeli barang atau jasa yang diharapkan akan memberikan manfaat bagi perusahaan saat sekarang atau untuk periode mendatang.

\section{Biaya Diferensial}

Hansen dan Mowen (2005 : 339) yang diterjemahkan oleh Dewi Fitriasari mengatakan pengertian biaya diferensial biaya masa depan yang berbeda pada masing - masing alternatif. Bambang Supomo (2012 : 103) menyatakan biaya diferensial adalah biaya yang berbeda dalam suatu kondisi, dibandingkan dengan kondisikondisi yang lain.

\section{Pengambilan Keputusan}

Menurut Darsono (2009 : 259) keputusan khusus yang diambil oleh manajer antara lain tentang :

1. Menolak atau menerima order khusus

2. Menutup divisi atau mengembangkan

3. Membuat sendiri atau membeli produk

4. Menjual atau memproses lebih lanjut suatu produk

5. Menyewakan atau menjual fasilitas perusahaan.

Adapun kriteria-kriteria adanya pesanan khusus sebagai berikut :

1. Biasanya konsumen yang melakukan pesanan khusus ini meminta harga dibawah harga jual normal bahkan sering kali harga yang diminta konsumen berada dibawah biaya penuh, karena biasanya pesanan khusus mencakup jumlah yang besar dan harga jualnya diatas biaya variabel.

2. Ada kapasitas produksi atau mesin yang belum seluruhnya terpakai atau menganggur dan masih mampu untuk melayani pesanan khusus.

3. Pertambahan biaya tidak melebihi pertambahan penghasilan dari pesanan khusus tersebut.

\section{Evaluasi Biaya Diferensial dalam Pengambilan Keputusan Menerima Atau Menolak Pesanan Khusus}

Menerima atau menolak pesanan khusus adalah dua alternatif keputusan yang dihadapi manajemen perusahan. Keputusan tentang harga jual produk dalam jangka pendek (masih ada kapasitas yang menganggur) dapat dilakukan dengan mempertimbangkan biaya diferensial. Pesanan khusus merupakan hal yang menarik 
meskipun harga jual produknya di bawah harga jual normal, dikarenakan pesanan khusus dapat memberikan tambahan pendapatan bagi perusahan sehingga laba perusahan dapat bertambah. Perusahan yang beroperasi pada kapasitas maksimum atau penuh, dalam pengerjaan pesanan khusus tersebut akan menyebabkan kenaikan biaya produksi yang bersifat tetap dan variabel. Sebaliknya jika perusahan beroperasi masih berada di bawah kapasitas maksimum, maka kemungkinan pengerjaan pesanan khusus tersebut tanpa menambah biaya overhead pabrik yang bersifat tetap, sehingga dalam hal ini biaya produksi yang bersifat variabel merupakan biaya diferensial. Pesanan khusus akan diterima apabila harga jual suatu produk lebih besar dari pada biaya variabel dan sebaliknya jika harga jual lebih kecil dari pada biaya variabel, maka pesanan khusus sebaiknya ditolak.

\section{Penelitian Terdahulu}

1. Auful (2013) dengan penelitian mengenai analisis biaya diferensial dalam pengambilan keputusan menerima atau menolak pesanan khusus perusahaan kecap "Kuda" Tulungagung yang bertujuan untuk menganalisis bagaimana biaya diferensial dapat mempengaruhi laba kontribusi dalam pesanan khusus. Penelitian ini menggunakan metode penelitian deskriptif. Hasil penelitian perusahaan hendaknya menerima pesanan khusus tersebut karena akan memberikan laba kontribusi bagi perusahaan. Terdapat persamaan dengan penelitian ini yakni terletak pada biaya diferensial dan pengambilan keputusan menerima atau menolak pesanan khusus. Dimana objek penelitian bergerak di bidang produksi kecap di Tulungagung.

2. Ardelia (2014) dengan penelitian mengenai analisis biaya diferensial dalam pengambilan keputusan menerima atau menolak pesanan khusus pada UD.Yunita Bakery yang bertujuan untuk menganalisis biaya diferensial dalam kaitannya dengan pengambilan keputusan menerima atau menolak pesanan khusus. Penelitian ini menggunakan metode deskripti. Hasil penelitian menunjukan bahwa dari alternatif yang diajukan mampu memberikan keuntungan bagi perusahaan. Terdapat persamaan dengan penelitian ini yakni terletak pada biaya diferensial dan pengambilan keputusan menerima atau menolak pesanan khusus. Dimana objek penelitian ini bergerak di bidang produksi roti.

3. Nancy (2014) dengan penelitian penggunaan informasi akuntansi diferensial dalam pengambilan keputusan menerima atau menolak pesasanan khusus pada UD.Vanela yang bertujuan untuk menganalisis penggunaan informasi akuntansi diferensial dalam pengambilan keputusan menerima atau menolak pesanan khusus. Penelitian ini menggunakan metode deskriptif kuantitatif. Hasil penelitian menunjukan bahwa keputusan untuk menerima pesanan khusus sudah tepat karena biaya-biaya relevan dengan pesanan khusus dibawah harga jual sehingga dapat meningkatkan laba. Tedapat persamaan dengan penelitian ini yakni terletak pada biaya diferensial dan pengamilan keputusan menerima atau menolak pesanan khusus. Dimana objek penelitian ini bergerak dibidang produksi pia.

\section{Jenis Penelitian}

\section{METODE PENELITIAN}

Penelitian ini menggunakan metode deskriptif kuantitatif. Yaitu metode yang menganalisis masalah dengan cara mendeskripsikannya pada data-data yang sudah ada, berupa tabel perhitungan biaya produksi untuk mengetahui perbandingan biaya produksi yang dapat memberikan gambaran maupun uraian jelas mengenai biaya diferensial dalam pengambilan keputusan menerima atau menolak pesanan khusus pada UD.Karema.

\section{Tempat dan Waktu Penelitian}

Tempat penelitian dilakukan pada UD.Karema yang berlokasi di desa Kolongan Atas Kecamatan Sonder Kabupaten Minahasa. Waktu dilaksanakan penelitian pada bulan September 2015.

\section{Prosedur Penelitian} berikut:

Adapun langkah-langkah yang dilakukan dalam pelaksanakan penelitian pada UD.Karema sebagai

1. Peneliti mengajukan surat permohonan penelitian untuk menyusun skripsi pada pimpinan UD.Karema.

2. Pada tahap ini, penelitian mengumpulkan data-data yang akan diperlukan dalam penyusunan skripsi, yaitu berupa adanya pesanan khusus, gambaran umum perusahaan, alur proses produksi, data penjualan, biaya bahan baku, biaya tenaga kerja, biaya tetap dan biaya variabel dengan dan tanpa pesanan khusus.

\section{Metode Pengumpulan Data}

Untuk mendapatkan data yang diperlukan dalam penelitian ini, maka peneliti melakukan penelitian lapangan seperti : 
1. Wawancara, yaitu teknik pengumpulan data dengan jalan mengadakan wawancara langsung dengan pihakpihak yang berwewenang dan bertanggung jawab seperti manajer dan karyawan untuk memberikan data dan keterangan yang dibutuhkan.

2. Pengamatan langsung, adalah teknik pengumpulan data dengan cara mengamati dan meninjau secara langsung. Pengamatan langsung bertujuan untuk meyakinkan bahwa data-data yang dihasilkan dari hasil wawancara adalah benar untuk menggambarkan kegiatan operasi perusahan tersebut.

\section{Jenis dan Sumber Data}

Kuncoro (2009:145) menyatakan bahwa data terbagi atas dua jenis, yaitu :

1. Data kuantitatif, yaitu data yang diperoleh dengan mengadakan pengamatan secara langsung pada perusahaan serta melakukan wawancara langsung dengan pihak pimpinan dan sejumlah personil yang ada kaitannya dengan penelitian ini.

2. Data kualitatif, yaitu data yang disajikan secara deskriptif atau berbentuk uraian atau penjelasan serta tidak dapat diukur dalam skala numerik.

Kuncoro (2009:148) mengungkapkan bahwa data terdiri dari dua jenis, yaitu :

1. Data primer merupakan data penelitian yang diperoleh dengan survei lapangan yang menggunakan semua metode pengumpulan data original.

2. Data sekunder merupakan data yang dikumpulkan oleh lembaga pengumpulan data dan publikasikan kepada masyarakat pengguna data.

\section{Metode Analisis Data}

Metode analisis data yang digunakan adalah metode deskriptif. Metode ini merupakan suatu metode yang bertujuan menguraikan, membandingkan, memberikan gambaran perusahaan dan menerangkan suatu data kemudian dianalisis sehingga dapat membuat kesimpulan sesuai dengan informasi dan data yang ada.

\section{Definisi Operasional}

Penelitian ini berjudul Evaluasi Biaya Diferensial dalam pengambilan keputusan menerima atau menolak pesanan khusus pada UD.Karema. Dimana akan disajikan maksud dari penelitian yang diteliti :

1. Biaya diferensial adalah berbagai perbedaan biaya diantara sejumlah alternatif pilihan yang dapat digunakan perusahaan.

2. Keputusan menerima atau menolak pesanan khusus merupakan suatu keadaan dimana manajemen diperhadapkan dengan pertimbangan untuk menetapkan harga jual dibawah harga jual normal karena adanya kapasitas menganggur.

\section{Gambaran Umum dan Sejarah Perusahaan}

\section{HASIL PENELITIAN DAN PEMBAHASAN}

UD.Karema adalah perusahaan yang bergerak dibidang tekstil di Sulawesi Utara. Istilah "Karema" diambil dari singkatan Kreasi Masyarakat Sulawesi Utara yang mengangkat kembali budaya masyarakat daerah. UD.Karema ini didirikan oleh ibu Onny Makardi Tambuwun. UD.Karema telah berhasil memproduksi kain bentenan yang telah hilang hampir dua ratus tahun lalu.

Tabel 1 Data Kapasitas Produksi UD.Karema Periode Oktober 2014-

September 2015

\begin{tabular}{lcc}
\hline \multicolumn{1}{c}{ Bulan } & $\begin{array}{c}\text { Kapasitas Max (per } \\
\text { potong kain) }\end{array}$ & Produksi Kain (per potong) \\
\hline Oktober 2014 & 25 & 15 \\
Nopember 2014 & 25 & 17 \\
Desember 2014 & 25 & 18 \\
Januari 2015 & 25 & 11 \\
Februari 2015 & 25 & 13 \\
Maret 2015 & 25 & 14 \\
April 2015 & 25 & 16 \\
Mei 2015 & 25 & 15 \\
Juni 2015 & 25 & 14
\end{tabular}




\begin{tabular}{lcc} 
Juli 2015 & 25 & 16 \\
Agustus 2015 & 25 & 16 \\
September 2015 & 25 & 15 \\
\hline Total & $\mathbf{3 0 0}$ & $\mathbf{1 8 0}$
\end{tabular}

Sumber : UD.Karema 2015

UD.Karema sebenarnya mampu memproduksi sebanyak 300 potong selama bulan Oktober 2014September 2015. Jadi selama tahun 2015 ada terdapat kapasitas menganggur sebesar 120 potong untuk memproduksi kain tenun. Dan pada bulan Agustus perusahaan mendapatkan pesanan khusus dari klien dengan jumlah 15 potong kain tenun. Berikut adalah informasi mengenai pesanan khusus yang diterima oleh UD.Karema pada bulan Agustus :

1. Pada bulan Agustus perusahaan mendapat pesanan khusus dari klien sebanyak 15 potong kain bentenan, yang menurut kesepakatan kain tersebut akan diambil pada akhir bulan September.

2. Harga yang ditawarkan klien tersebut untuk per potong kain adalah Rp. 2.400.000, sedangkan harga sesungguhnya adalah Rp.2.800.000.

Tabel 2 Biaya Bahan Baku untuk Memproduksi Kain periode

Oktober 2014-September 2015

\begin{tabular}{lc}
\hline Keterangan & Jumlah (Rp) \\
\hline Benang & 112.746 .000 \\
Pewarna & 24.679 .000 \\
\hline Total & 137.425 .000 \\
\hline
\end{tabular}

Sumber : UD.Karema 2015

Tabel 3 Biaya Tenaga Kerja Langsung Periode Oktober 2014-September 2015

\begin{tabular}{lcccc}
\hline Keterangan & $\begin{array}{c}\text { Hari Kerja } \\
\text { Setahun } \\
\text { (Hari) }\end{array}$ & $\begin{array}{c}\text { Jumlah } \\
\text { Tenaga } \\
\text { Kerja } \\
\text { Langsung }\end{array}$ & $\begin{array}{c}\text { Upah Kerja } \\
\text { per Hari (Rp) }\end{array}$ & $\begin{array}{c}\text { Jumlah BTKL } \\
\text { (Rp) }\end{array}$ \\
\hline Supervisor & 312 & 1 & 75.000 & 23.400 .000 \\
Penenun & 312 & 5 & 65.000 & 101.400 .000 \\
\hline Total & & & & $\mathbf{1 2 4 . 8 0 0 . 0 0 0}$ \\
\hline
\end{tabular}

Sumber : UD.Karema 2015

Tabel 4 Biaya Overhead Pabrik Periode Oktober 2014-September 2015

Keterangan Jumlah Biaya Overhead Pabrik (Rp)

\begin{tabular}{lr}
\hline Biaya tenaga kerja tidak langsung & 62.400 .000 \\
Biaya listrik dan air & 7.200 .000 \\
Biaya telepon & 1.320 .000 \\
Biaya perbaikan mesin & 800.000 \\
\hline Total & $\mathbf{7 1 . 7 2 0 . 0 0 0}$ \\
\hline
\end{tabular}

Sumber : UD.Karema 2015

Tabel 5 Biaya Administrasi dan Umum Periode Oktober 2014-September 2015

\section{Keterangan}

Jumlah Biaya Administrasi \& Umum (Rp)

\begin{tabular}{lc}
\hline $\begin{array}{l}\text { Biaya pemeliharaan bangunan dan } \\
\text { halaman }\end{array}$ & 1.100 .000 \\
\hline Total & $\mathbf{1 . 1 0 0 . 0 0 0}$ \\
\hline
\end{tabular}


Sumber : UD.Karema 2015

Tabel 6 Biaya Pemasaran Periode Oktober 2014-September 2015

$\begin{array}{cc}\text { Jumlah Biaya } \\ \text { Keterangan } & \text { Pemasaran (Rp) }\end{array}$

\begin{tabular}{ll}
\hline Biaya Angkutan/Transportasi & 770.000 \\
\hline Total & $\mathbf{7 7 0 . 0 0 0}$ \\
\hline
\end{tabular}

Sumber : UD.Karema 2015

Tabel 6 menunjukkan bahwa biaya pemasaran UD.Karema pada tahun 2015 adalah sebesar Rp.770.000,00.

Tabel 7 Laporan Laba Rugi Perusahaan sebelum ada Pesanan Khusus

\begin{tabular}{|c|c|}
\hline Penjualan & \\
\hline Kain & $\underline{\mathrm{Rp} .504 .000 .000}$ \\
\hline Total penjualan & Rp.504.000.000 \\
\hline Biaya bahan baku & Rp. 137.425.000 \\
\hline Biaya tenaga kerja langsung & Rp. 124.800 .000 \\
\hline Biaya overhead pabrik & Rp. 71.720 .000 \\
\hline Harga pokok produksi & (Rp. 333.945.000) \\
\hline Laba kotor & Rp. 170.055 .000 \\
\hline Biaya operasional : & \\
\hline Adm \& umum & Rp. 1.100 .000 \\
\hline Biaya pemasaran & Rp. $\quad 770.000$ \\
\hline Total biaya operasional & (Rp. 1.870 .000$)$ \\
\hline Laba usaha & Rp.168.185.000 \\
\hline
\end{tabular}

Sumber : Data diolah 2015

Tabel 8 Harga Pokok Produksi Dalam Memproduksi Kain Menggunakan

Biaya Diferensial per unit Periode Oktober 2014-September 2015 (Rp)

Biaya Bahan Baku

$\begin{array}{ll}\text { Pewarna } & 626.388,89\end{array}$

Benang $137.083,33$

\begin{tabular}{ll} 
Total Biaya Bahan Baku & $763.472,22$ \\
\hline
\end{tabular}

Biaya Tenaga Kerja Langsung

$\begin{array}{ll}\text { Supervisor } & 130.000,00\end{array}$

$\begin{array}{ll}\text { Penenun } & 563.333,33\end{array}$

Total Biaya Tenaga Kerja Langsung $\quad 693.333,33$

Biaya Overhead Pabrik

Biaya Listrik \& Air (Variabel) $\quad 40.000,00$

\begin{tabular}{lr}
\hline Total Biaya Overhead Pabrik & $40.000,00$ \\
\hline Total Biaya Diferensial Per Unit & $\mathbf{1 . 4 9 6 . 8 0 5 , 5 5}$ \\
\hline
\end{tabular}

Sumber : Data diolah 2015

Tabel 9 Perhitungan Laba Rugi Jika Menerima Pesanan Khusus

Penjualan :

Kain

Total Penjualan

Biaya Bahan Baku

Biaya Tenaga Kerja Langsung 148.877 .083

Biaya Overhead Pabrik

72.320 .000

Harga Pokok Produksi

\begin{tabular}{rr}
546.000 .000 & \\
148.877 .083 & \\
135.200 .000 & \\
72.320 .000 \\
\hline
\end{tabular}


Biaya Operasional :

Administrasi \& Umum

1.100 .000

Pemasaran

770.000

Total Biaya Operasional

(1.870.000)

Laba Usaha

187.732.917

Sumber : Data diolah, 2015

Tabel 10 Evaluasi Biaya Diferensial dengan Pesanan Khusus atau Tanpa Pesanan Khusus pada UD.Karema Periode Oktober 2014-September 2015

\begin{tabular}{lrrr} 
Keterangan & $\begin{array}{c}\text { Menerima Pesanan } \\
\text { Khusus }\end{array}$ & $\begin{array}{c}\text { Menolak } \\
\text { Pesanan Khusus }\end{array}$ & Diferensial \\
\hline Penjualan & 546.000 .000 & 504.000 .000 & 42.000 .000 \\
\cline { 2 - 4 } BBB & 148.877 .083 & 137.425 .000 & 11.452 .083 \\
BTKL & 135.200 .000 & 124.800 .000 & 10.400 .000 \\
BOP & 72.320 .000 & 71.720 .000 & 600.000 \\
\cline { 2 - 4 } HPP & 356.397 .083 & 333.945 .000 & 22.452 .083 \\
\cline { 2 - 4 } Laba Kotor & 189.602 .917 & 170.055 .000 & 19.547 .917 \\
Biaya Operasional : & 1.100 .000 & & - \\
Administrasi \& Umum & 770.000 & 1.100 .000 & - \\
Pemasaran & $(1.870 .000)$ & 770.000 & - \\
Total Biaya Operasional & $\mathbf{1 8 7 . 7 3 2 . 9 1 7}$ & $\mathbf{1 6 8 . 1 8 5 . 0 0 0}$ & $\mathbf{1 9 . 5 4 7 . 9 1 7}$ \\
\cline { 2 - 4 } Laba Usaha & & &
\end{tabular}

Sumber : Data diolah, 2015

Harga jual per unit kain pesanan khusus dibawah harga normal sebesar Rp.2.400.000 sedangkan harga normal Rp.2.800.000. Berdasarkan tabel 10 dapat dilihat perbedaan diferensial penjualan sebesar Rp.42.000.000,diferensial biaya bahan baku sebesar Rp.11.452.083, diferensial biaya tenaga kerja langsung sebesar Rp.10.400.000, diferensial biaya overhead pabrik Rp.600.000, diferensial harga pokok produksi sebesar Rp.22.452.083 sehingga menghasilkan diferensial laba kontribusi sebesar Rp.19.547.917 apabila kita menerima pesanan khusus ini.

Berikut ini disajikan perhitungan biaya diferensial dan variable cost dalam pengambilan keputusan :

$\begin{array}{llr} & =\mathrm{Rp} .1 .496 .805,53 \\ \text { Biaya operasional/unit } & & =\mathrm{Rp} . \\ \text { Variable Cost } & & =\mathrm{Rp} .1 .496 .805,53\end{array}$

Berdasarkan perhitungan tersebut dapat diketahui bahwa variable cost (jumlah biaya untuk memproduksi 1 potong kain) sebesar Rp.1.496.805,53 lebih rendah dibandingkan dengan harga jual yang dijual yang ditawarkan oleh klien sebesar Rp.2.400.000. Pengambilan keputusan untuk menerima suatu pesanan khusus dapat diambil jika harga jual lebih besar dari pada Variable Cost (Harga jual > Variable Cost). Berdasarkan evaluasi biaya diferensial (Rp.2.400.000,00 > Rp.1.496.805,53). Jadi perusahaan dapat menerima pesanan khusus ini karena akan memberikan laba kontribusi kepada perusahan sebesar Rp.19.547.917.

\section{Kesimpulan}

\section{PENUTUP}

Dari hasil penelitian mengenai evaluasi biaya diferensial dalam pengambilan keputusan menerima atau menolak pesanan khusus pada UD.Karema, maka dapat ditarik kesimpulan sebagai berikut :

1. Berdasarkan hasil evaluasi mengenai biaya diferensial, khususnya pengambilan keputusan menerima atau menolak pesanan khusus, menunjukkan bahwa biaya diferensial sangat bermanfaat terhadap 
manajemen UD.Karema dalam memperoleh informasi untuk membandingkan keputusan manakah yang lebih menguntungkan dalam pengambilan keputusan menerima atau menolak terhadap pesanan khusus.

2. Berdasarkan hasil evaluasi mengenai biaya diferensial, khususnya pengambilan keputusan menerima atau menolak pesanan khusus menunjukkan bahwa dari alternatif yang ada mampu memberikan laba kontribusi sebesar Rp.19.547.917 kepada perusahan.

Saran

Berdasarkan hasil penelitian yang telah disimpulkan di atas maka penulis menyarankan kepada perusahan UD.Karema sebaiknya perusahan menerapkan perhitungan biaya diferensial, supaya di hari yang akan datang perusahan dapat melakukan pengambilan keputusan menerima atau menolak pesanan khusus dengan tepat dan dapat meningkatkan laba perusahan.

\section{DAFTAR PUSTAKA}

Arfan, ikhsan. 2009, Pengantar Praktis Akuntansi. Edisi Pertama. Graha Ilmu, Yogyakarta

Darsono, dkk. 2009. Akuntansi Manajemen. Jilid 1. Edisi ke empat. Erlangga, Jakarta

Hansen, D.R. dan M.M. Mowen. 2005. Management Accounting penerjemah Dewi Fitriasari dan Deni Amos Kwary. Edisi-7 Buku-1 Jakarta : Penerbit Salemba Empat

Hidayati, Auful, 2013. Analisis Biaya Diferensial sebagai Dasar Pengambilan Keputusan Menerima atau Menolak Pesanan Khusus pada Perusahaan Kecap Cap "Kuda” Tulungagung. Jurnal Administrasi Bisnis (JAB). Vol 11 No.1 Juni 2014.

Horngren, Datar, Foster, George, 2009. Akuntansi Biaya dengan Penekanan Manajerial Jilid 1.

Lalenoh, Ardelia, 2014. Analisis Biaya Diferensial dalam Pengambilan Keputusan Menerima atau Menolak Pesanan Khusus Pada UD. Yunita Bakery. Jurnal EMBA ISSN 2303-1174. Vol.2 No.4 Desember 2014, Hal 743-750Erlangga. Jakarta.

Kautsar, Salman, 2013. Akuntansi Biaya, Cetakan Pertama, Akademia Permata Jakarta.

Krismiaji,Aryani, 2011. Akuntansi Manajemen. UPP STIM YKPN. Yogyakarta.

Kuncoro, M, 2009. Metode Riset untuk Bisnis dan Ekonomi bagaimana Meneliti dan menulis Tesis. Edisi 3. Erlangga. Jakarta.Salvatore, Dominick. 2005. Ekonomi Manajerial dalam Perekonomian Global. Jakarta : Salemba 4.

Simamora, Henry. 2012. Akuntansi Manajemen. Edisi III. Star Gate Publisher. Duri, Riau.

Supomo, Bambang. 2012. Akuntansi Manajemen Suatu Sudut Pandan.Penerbit: BPFE, Yogyakarta.

Ticoalu, Nancy. 2014. Penggunaan Informasi Akuntansi Diferensial dalam Pengambilan Keputusan terhadap Pesanan Khusus pada UD.Vanela. Jurnal EMBA ISSN 2303-1174. Vol.2 No.1 Maret 2014, Hal 686695. 